\title{
THE FORMING OF MAGNESIUM ALLOY FORGINGS FOR AIRCRAFT AND AUTOMOTIVE APPLICATIONS
}

\author{
Anna Dziubińska' ${ }^{1}$ Andrzej Gontarz'1 , Mieczysław Dziubiński', Marcin Barszcz²
}

1 Faculty of Mechanical Engineering, Lublin University of Technology, Nadbystrzycka 36, 20-618 Lublin, Poland, e-mail: a.dziubinska@pollub.pl

2 Fundamentals of Technology Faculty, Lublin University of Technology, Nadbystrzycka 36, $20-618$ Lublin, Poland

Received: 2016.05 .15

Accepted: 2016.07.05

Published: 2016.09.01

\begin{abstract}
The paper presents the theoretical and technological aspects of forming magnesium alloy parts for aircraft and automotive applications. The main applications of magnesium alloys in the aircraft and automotive industries are discussed. In addition, the forging technology for magnesium alloys is generally described, with a particular emphasis on wrought alloys. A brief outline of the state of the art in the forging of magnesium alloys is given based on a survey of the specialist literature and the results of previous research by the authors.
\end{abstract}

Keywords: magnesium alloy, forging, aircraft applications, automotive applications, metal forming, experimental tests.

\section{INTRODUCTION}

Magnesium alloys are light metal alloys with a vast spectrum of applications. These alloys are used, among others, in the aircraft, automotive, armaments, electronic, textile, sports, medical and building industries.

The aircraft industry uses a wide range of magnesium alloy parts, from gearbox and engine components, gearbox casts, wings, fuselage skin, door, wheels and undercarriage, to dashboard panels and seat components. To give an example, the Boeing 727 aircraft contains approx. 1200 magnesium parts. The applications for magne-

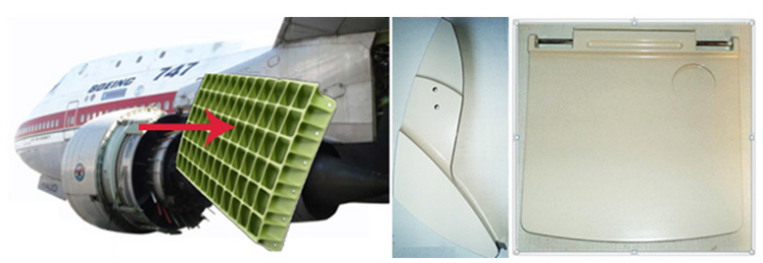

Fig. 1. Examples of application for magnesium alloys in Boeing 747: wing and seat components [18] sium alloys in the aircraft industry are presented in Figures 1 and 2 [18, 26, 29].

As for the automotive industry, one can observe that more and more vehicle parts are made

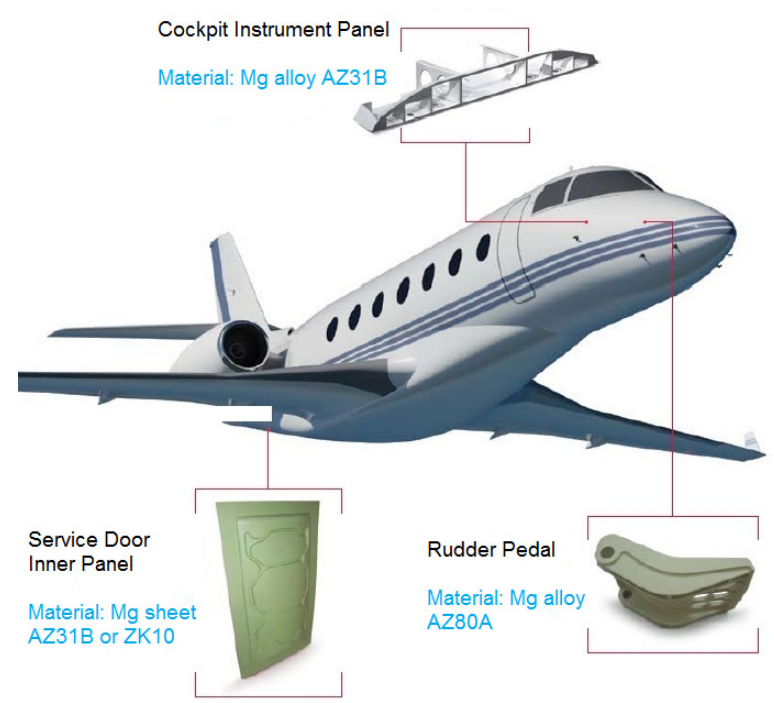

Fig. 2. Applications for magnesium alloys in the aircraft industry [3] 


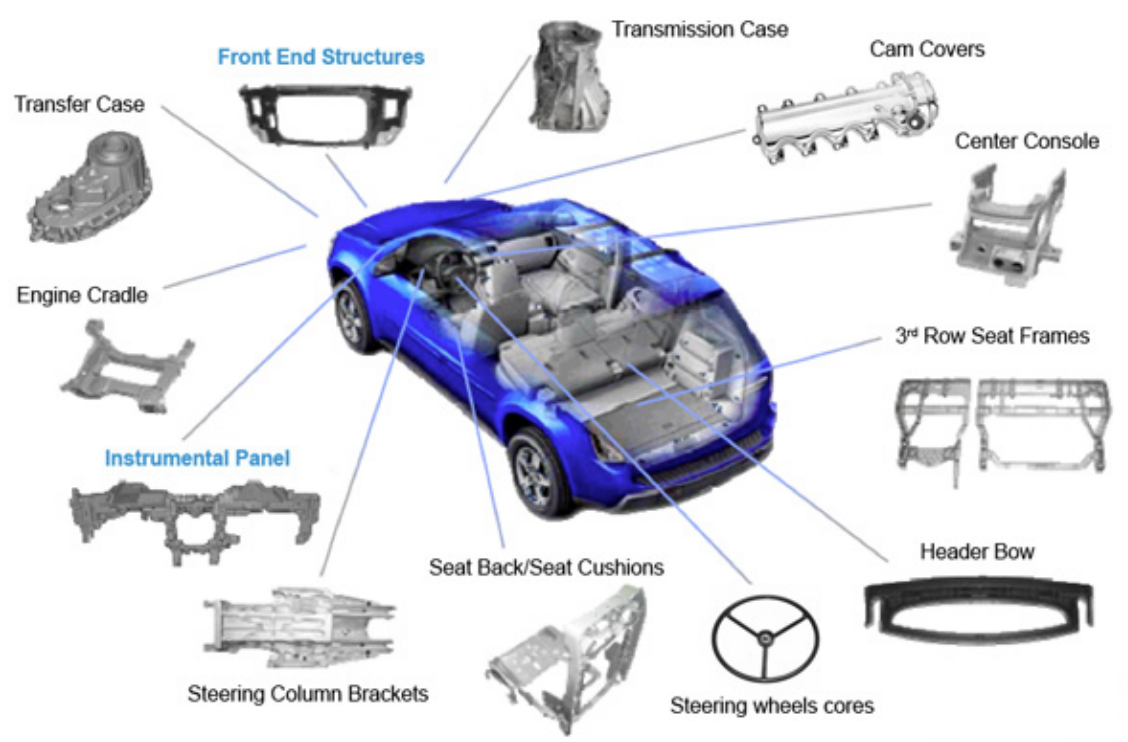

Fig. 3. Examples of applications for magnesium alloys in the automotive industry [15]

of magnesium alloys. This results from the European Union directives on saving energy, including fuel [31]. The application of magnesium alloys in automotive design enables weight reduction of the entire vehicle, and thus reduced fuel consumption. The reduction of vehicle weight by $100 \mathrm{~kg}$ gives a saving of up to 0.4 liter of fuel per $100 \mathrm{~km} \mathrm{[9].} \mathrm{The} \mathrm{following} \mathrm{parts} \mathrm{are} \mathrm{made} \mathrm{of}$ magnesium alloys in the automotive sector: engine and body components, cylinder head covers, the frames of seats and sunroofs, pedal brackets, driving wheels, and many more (Fig. 3) [6].

Similarly to other light metal alloys, magnesium alloys are processed by metal forming processes $[1,12,27]$. They can be deformed by extrusion, rolling, press forming, drawing, pressing and forging $[4,5,7,13,30]$. This paper describes the forging processes for magnesium alloys for aircraft and automotive applications.

\section{DESIGN OF A FORGING TECHNIQUE FOR MAGNESIUM ALLOYS}

Magnesium alloy forging is difficult due to the peculiar properties of these materials, including their low plasticity, narrow forming temperature ranges and low sensitivity to strain rate. Given the above, it is no wonder that in Poland there are no forging plants specializing in the production of magnesium alloy forgings. It should also be mentioned that the difficulty in employing this technique stem from the lack of specialist devices ensuring the condition for forming these alloys, along with the lack of experienced personnel for the metal forming of these alloys. In the world, the forging of magnesium alloys is done using specialist presses provided with expensive heating systems. The manufacturing companies that have implemented the technology for forging magnesium alloys include Otto-Fuchs a)

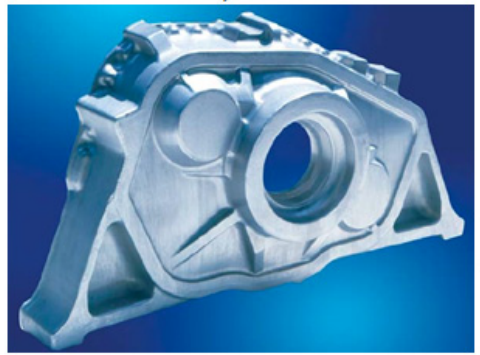

b)

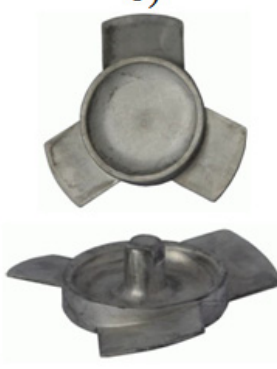

c)

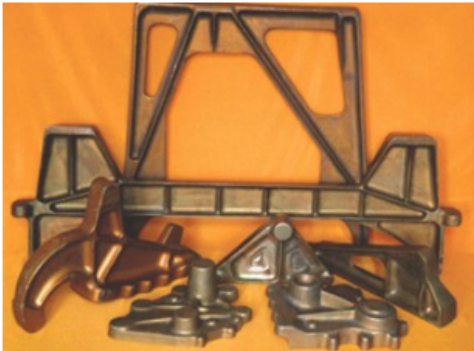

Fig. 4. Magnesium alloy parts manufactured by: a) Otto-Fuchs (gear casing cover made of ZK30 alloy) [19],

b) Weisensee Warmpressteile (impeller wheel) [24], c) KUMZ (AZ61A or ZK60A alloy forgings for aircraft and automotive applications) [20] 
and Weisensee Warmpressteile from Germany and KUMZ from Russia (Fig. 4). Nonetheless, the above manufacturers of magnesium alloy forgings do not sell their products on the Polish market.

According to the specialist literature, the die forging of magnesium alloys is done using hydraulic or mechanical presses operated at low speeds and equipped with tool heating systems $[2,1,22]$. Occasionally, magnesium alloys are formed by hammer forging, with the exception of AZ31B alloy which exhibits high deformability [27]. Magnesium alloys that are most often formed by press forging include AZ31B, AZ61A, AZ80A and ZK60ZA. The above AZ alloys exhibit higher plasticity at lower aluminum content, and they are more widely applied in the industry. On the other hand, ZK magnesium alloys are used for special solutions due to their slightly higher deformability. Nevertheless, some casting alloys, e.g. AZ90, can also be formed by precision forging [32].

The majority of wrought magnesium alloys have the forging temperature range $290 \div 450^{\circ} \mathrm{C}$ [8]. Due to the narrow range of hot forming temperatures, the tools must be pre-heated to a temperature ranging approx. from $205^{\circ} \mathrm{C}$ to $350^{\circ} \mathrm{C}$. Table 1 lists the recommended forging temperatures of billet and tools for selected magnesium alloys [8]. The maintaining of the assumed temperature of dies in magnesium alloy forming requires the use of specialist heating systems located in the tools. With these alloys it is recommended that the forging process be run under isothermal conditions or similar [33]. The main advantages of running the forging process under isothermal conditions include increasing the plasticity of magnesium alloys, reducing force parameters of the process, producing forgings with a better structure due to reduced non-uniformity of strains.

To improve the hot forming conditions for magnesium alloy forging, various lubricating agents are used such as colloidal graphite, molybdenum disulfide, mineral oils, waxes and fats. Good friction is also ensured by the use of plastic films [21].

Failure modes that can occur in the forging of magnesium alloys include cracking and lapping. Examples of cracking are given in Figure 5a, which shows a forging with defects produced by hammer forging. This defect is caused by too high strain rate and too high drop in the temperature due to the heat transfer between the metal and the tools as well as the environment. Under the applied forming conditions, the plasticity of WE43 alloy significantly decreases.
Table 1. Recommended forging temperatures for magnesium alloys [8]

\begin{tabular}{|c|c|c|}
\hline \multirow{2}{*}{ Alloy } & \multicolumn{2}{|c|}{ Temperature $\left[{ }^{\circ} \mathrm{C}\right]$} \\
\hline & Billet & Tools \\
\hline \multicolumn{3}{|c|}{ Commercial alloys } \\
\hline ZK21A 300 & $300-370$ & $260-315$ \\
\hline AZ61A 315 & $315-370$ & $290-345$ \\
\hline AZ31B & $290-345$ & $260-315$ \\
\hline \multicolumn{3}{|c|}{ High-strength alloys } \\
\hline ZK60A & $290-385$ & $205-290$ \\
\hline AZ80A & $290-400$ & $205-290$ \\
\hline \multicolumn{3}{|c|}{ Elevated temperature alloys } \\
\hline HM21A & $400-525$ & $370-425$ \\
\hline EK31A & $370-480$ & $345-400$ \\
\hline \multicolumn{3}{|c|}{ Special alloys } \\
\hline ZE42A & $290-370$ & $300-345$ \\
\hline ZE62 & $300-345$ & $300-345$ \\
\hline QE22A & $345-385$ & $315-370$ \\
\hline
\end{tabular}

a)

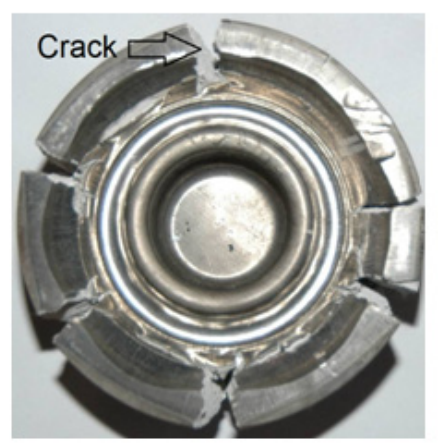

b)

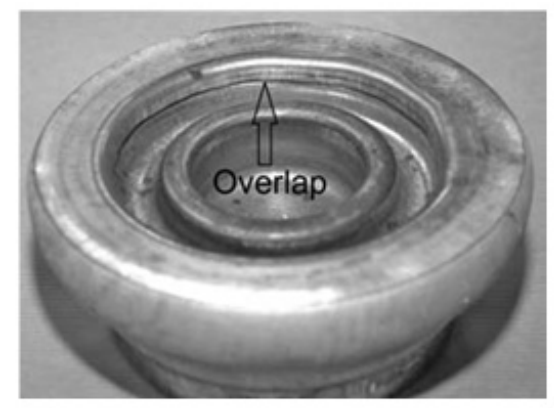

Fig. 5. Failure modes in the forging process for magnesium alloys: a) metal cracking in a forging process for WE43 alloy, b) overlapping in an AZ31 alloy hub produced without upsetting

Lapping usually occurs in the places of a sudden change in the direction of metal flow, which is particularly characteristic of parts with complex shapes. This defect is typical of forging processes for all metals. Examples of lapping are shown in a AZ31 alloy hub formed without the upsetting operation (Fig. 5b). 
a)

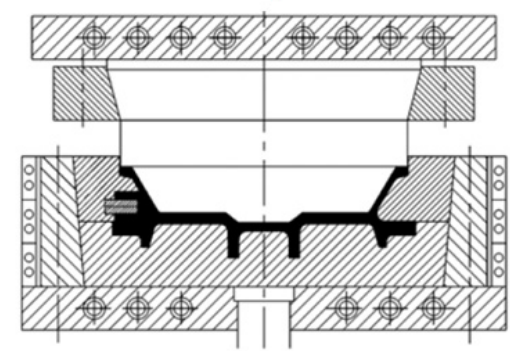

c)

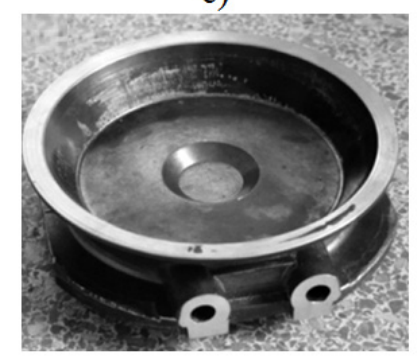

b)

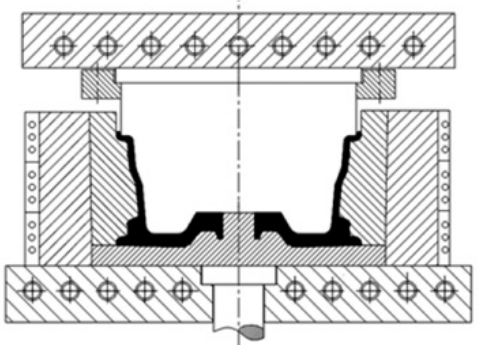

d)

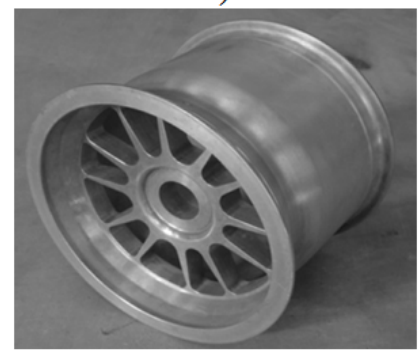

Fig. 6. Schematic design of the forging tools for a bracket (a) and wheel rim (b) and examples of produced bracket (c) and wheel rim (d) [32]

EXAMPLES OF FORGING PROCESSES FOR MAGNESIUM ALLOY PARTS FOR AIRCRAFT AND AUTOMOTIVE OPERATIONS

\section{Isothermal forging process for AZ31 alloy bracket and AZ80 alloy car wheel rim using a hydraulic press}

The study [33] describes an isothermal forging process for an AZ31 alloy bracket and an AZ80 alloy car wheel rim (Figs. 6c and 6d). In this process, the billet is heated to a temperature of $360 \div 400{ }^{\circ} \mathrm{C}$. The process is run using a hydraulic press with a load of $6.3 \mathrm{MN}$ and the slide speed set to $16 \mathrm{~mm} / \mathrm{s}$, lubricated by colloidal graphite. Figures $6 \mathrm{a}$ and $6 \mathrm{~b}$ show a schematic design of the tools used for forging such parts. As it can be seen in the figures, the tools are provided with heating systems (marked by circles) ensuring the realization of the process under isothermal conditions.

\section{Forging process for AZ80 alloy connecting- rod using a hydraulic press}

In their 2002 study, V. Kevorkijan et al. presented the forging process for an AZ80 alloy connecting-rod [23]. The part as formed using a hydraulic press with a load of $10 \mathrm{MN}$ at the temperature set to 300 and $400{ }^{\circ} \mathrm{C}$, and the strain rate set to $0,1 \mathrm{~s}-1$; the press was $1 \mathrm{u}$ bricated with a mixture of oil, graphite and an- imal fat. The produced connecting-rods were subjected to thermal processing (ageing) at a temperature of $177 \pm 5{ }^{\circ} \mathrm{C}$ for 24 hours with aircooling (T5).

\section{Hydraulic press forging process for connect- ing-rod and flat part made of ZK60A alloy}

The die forging tests of magnesium alloy ZK60A were conducted using a vertical hydraulic press with a maximum load of $2.5 \mathrm{MN}$ for a selection of forging shapes (after the removal of flash) shown in Figs. 7 a, b [28]. The billet was in form of extruded bars described with the diameters $26 \mathrm{~mm}$ and $35 \mathrm{~mm}$. The billet was heated to the temperatures $350{ }^{\circ} \mathrm{C}$ and $400{ }^{\circ} \mathrm{C}$. The process was run using specially designed die impressions (Figs. 7 c, d) which were heated to a temperature of $250^{\circ} \mathrm{C}$. Graphite-based lubrication was applied to avoid the sticking of metal to the dies.

\section{Closed-die forging process for casting alloy AZ31 and preliminarily wrought alloy AZ61}

The forging process was performed using a hydraulic press with a load of $1 \mathrm{MN}$, with the slide speed set to $v=1 \mathrm{~mm} / \mathrm{s}$ [32]. The forming process was run for casting alloy AZ31 and preliminarily wrought alloy AZ61. Two types of billet were used: $\mathrm{h} / \mathrm{d}=0.8$ and $\mathrm{h} / \mathrm{d}=2.5$, resulting from the billet's central position in 
a)

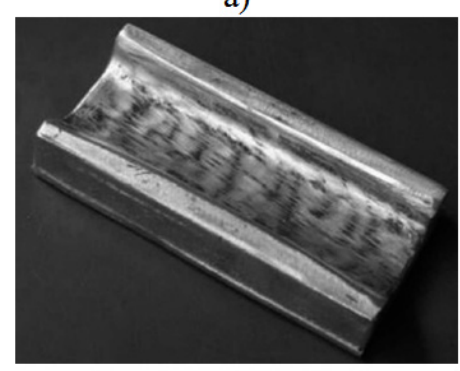

c)

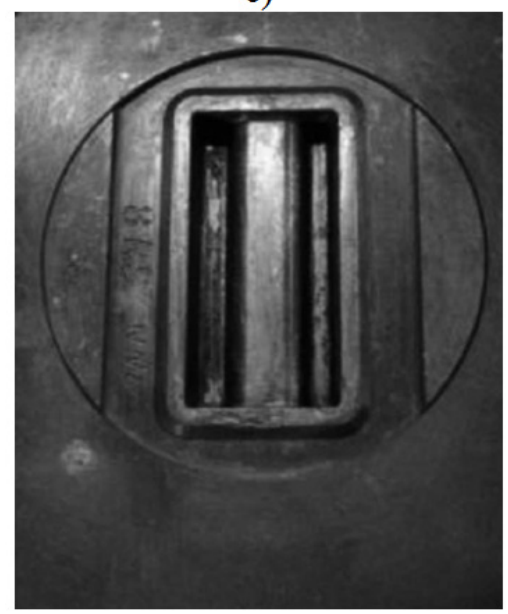

b)

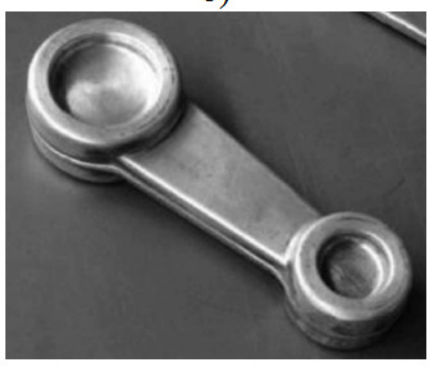

d)

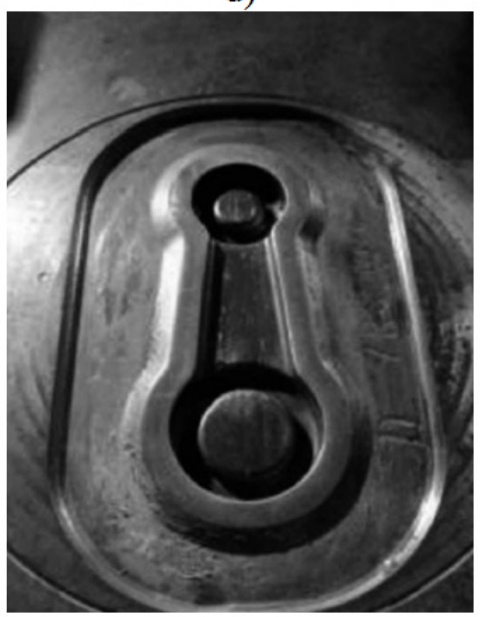

Fig. 7. Produced ZK60A alloy flat forging (a) and connecting rod (b), and the dies used in the tests (c), (d) [28]

the die impression. A schematic design of the forging process for the two variants is shown in Figure 8. The process was run using a molybdenum disulfide-based lubricant. Examples of forgings produced in the tests are shown in Figures 9 and 10 .

a)



Press forging process for an aircraft windowframe made of casting alloy AZ80 and wrought alloy AZ31

The 2010 report on the project MAGFORMING - "Development of New Magnesium Form-

Fig. 8. Schematic design of the forging process for the billet: a) $h / d=0.8$ and b) $h / d=2.5$, where: 1 punch; 2 die; 3 thermocouples; 4 mandrel; 5 billet; 6 heating system; 7 ejector [33] 

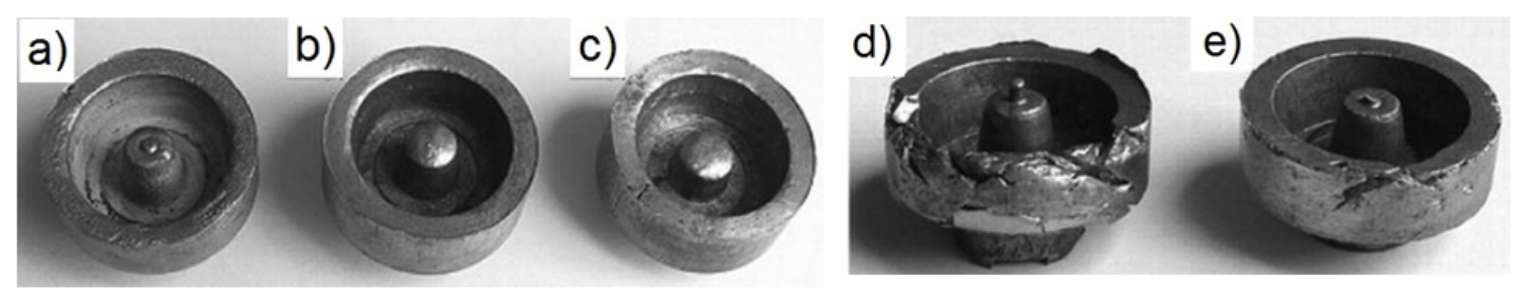

Fig. 9. AZ31 alloy forgings produced by closed-die forging from the billet $\mathrm{h} / \mathrm{d}=0.8$ formed at the temperatures: a) $300{ }^{\circ} \mathrm{C}$, b) $230{ }^{\circ} \mathrm{C}$, c) $200{ }^{\circ} \mathrm{C} ; \mathrm{h} / \mathrm{d}=2.5$ formed at the temperatures: d) $200^{\circ} \mathrm{C}$, e) $280^{\circ} \mathrm{C}[32]$
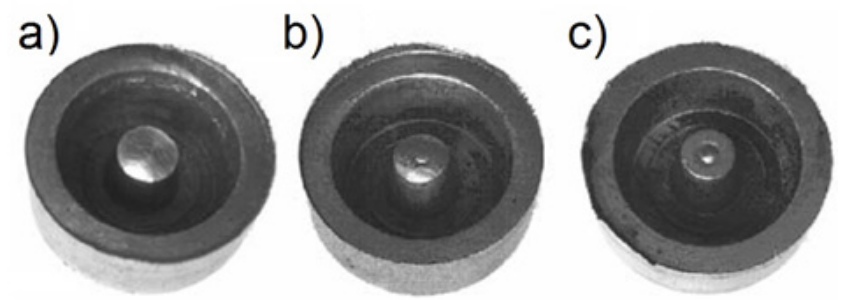

Fig. 10. Preliminarily wrought AZ61 alloy forgings produced by closed-die forging tests from the billet $\mathrm{h} / \mathrm{d}=0.8$ formed at temperatures: a) $150{ }^{\circ} \mathrm{C}$, b) $200{ }^{\circ} \mathrm{C}$, c) $350{ }^{\circ} \mathrm{C}$ [32]

a)

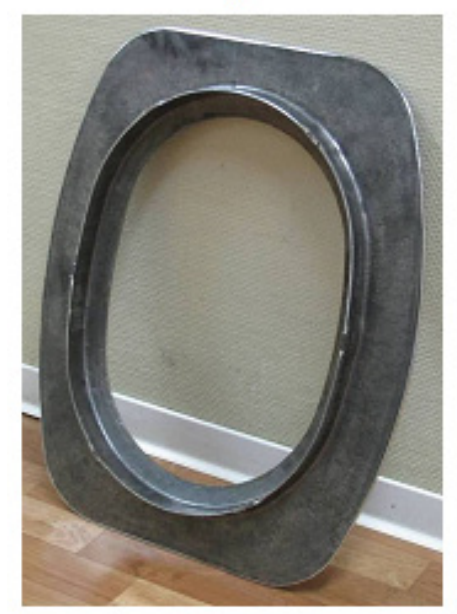

b)

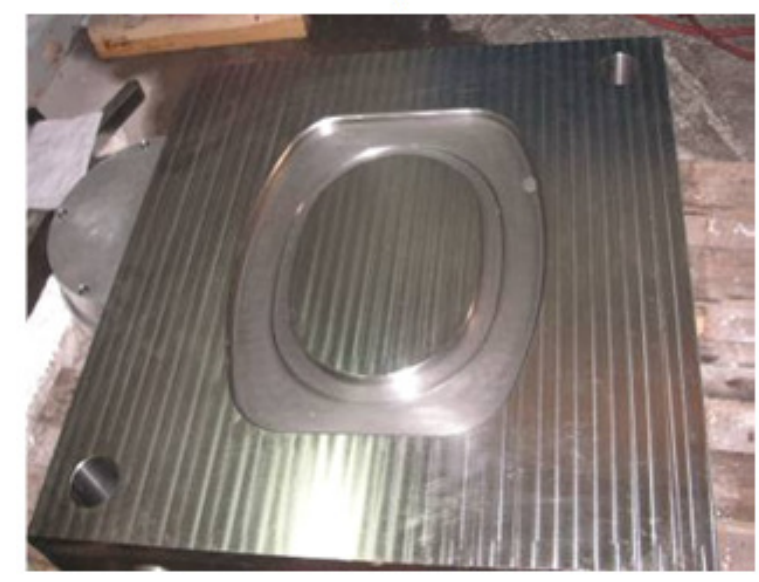

Fig. 11. Shape of an Airbus aircraft windowframe made of magnesium alloy and tool used for forging [16]

ing Technologies for the Aeronautics Industry," coordinated by PALBAM Metal Works, presents the forging process for producing an Airbus aircraft windowframe made of casting alloy AZ80 and wrought alloy AZ31 (Figs. 11a) [16]. The forming process was run in closed die impressions using a hydraulic press with a load of $50 \mathrm{MN}$, at the temperature set to $320 \div 330^{\circ} \mathrm{C}$. The tools used in the experiments are shown in Figure $11 \mathrm{~b}$.

\section{Isothermal forging process for producing a compressor rotor made of AZ80 and WE43 alloys using a hydraulic press}

The work [16] describes the forging process for a compressor rotor made of AZ80 and WE43 alloys, shown in Figure 12. The billet used had the dimensions $\varnothing 134 \times 173 \mathrm{~mm}$; the tools were heated to a temperature of $350^{\circ} \mathrm{C}$ and their speed was set to $\mathrm{v}=10 \mathrm{~mm} / \mathrm{s}$.

\section{Isothermal forging process for aircraft door lock set made of AZ80 and WE43 alloys using a hydraulic press}

The isothermal forging process for an aircraft door lock set made of AZ80 and WE43 alloys was performed on a $\varnothing 65 \times 60 \mathrm{~mm}$ billet at a temperature of $300{ }^{\circ} \mathrm{C}$ with a speed of $10 \mathrm{~mm} / \mathrm{s}$ [16]. We used specially designed die impressions provided with heating systems, shown in Figure 13. The produced part is shown in Figure 14. 
a)

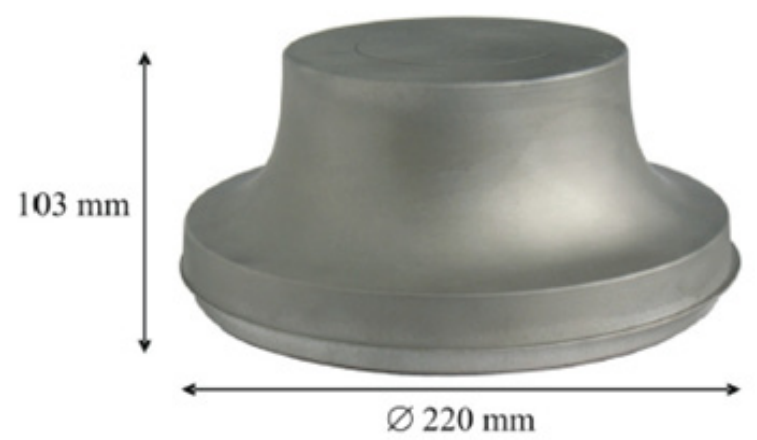

b)

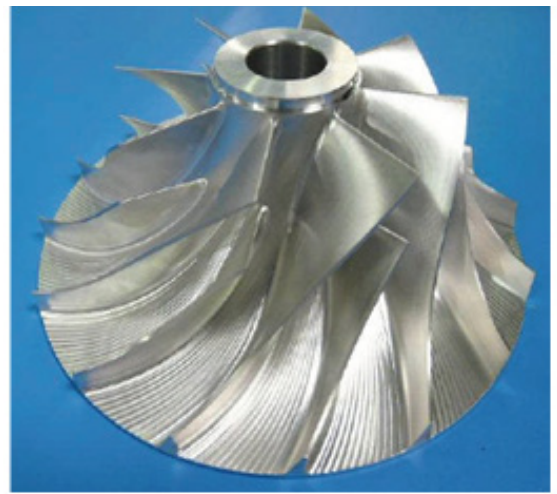

Fig. 12. Semi-finished compressor rotor (a) and finished part after machining (b) [16]

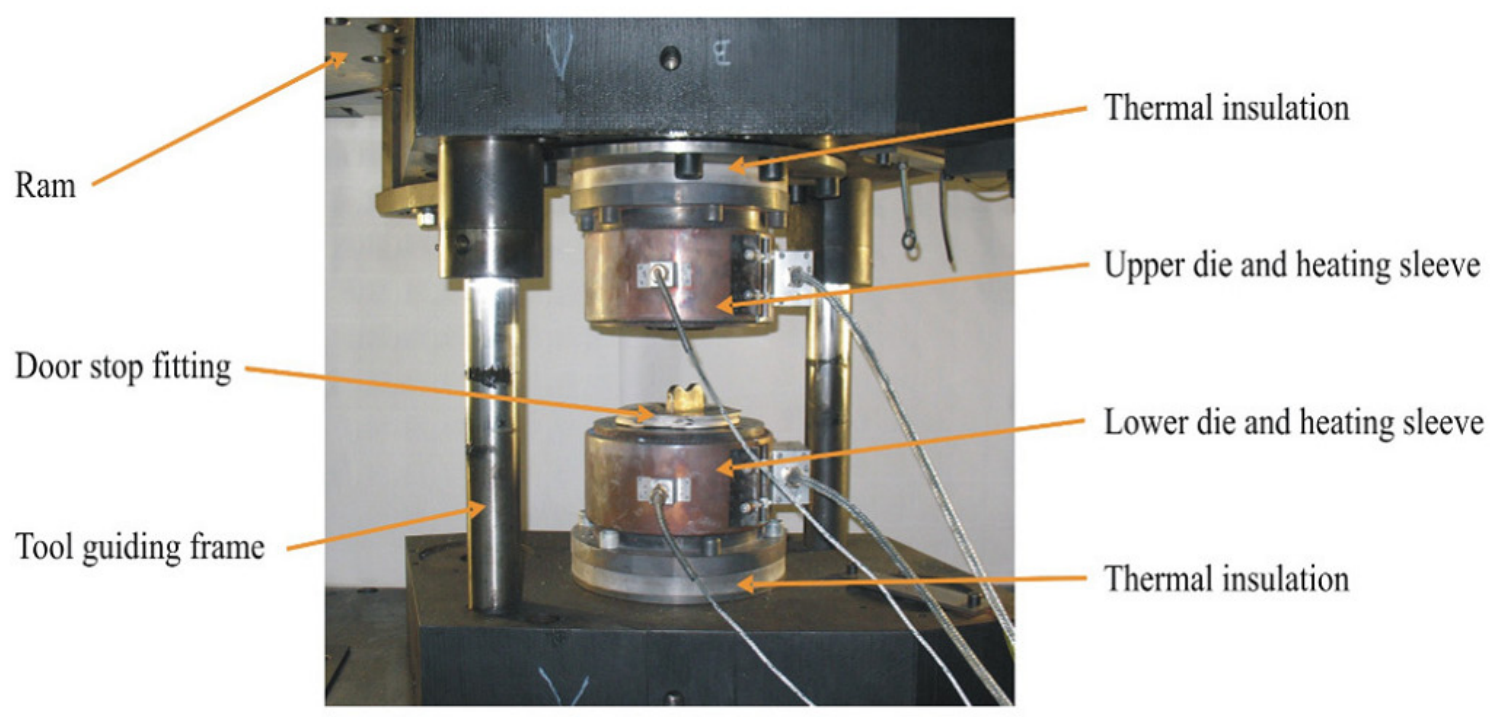

Fig. 13. Tools used for forging aircraft door lock set [16]

\section{Forging process for WE43 alloy compressor casing}

The forging process for a WE43 alloy compressor casing was run in two operations (Fig. 15) [17]. The final shape of the part after the forging process is shown in Figure 16. The weight of the magnesium alloy part was $1.06 \mathrm{~kg}$, while that of a part made of aluminum alloy would be $1.6 \mathrm{~kg}$.

\section{Hammer forging process for an AZ31 alloy aircraft hub}

The hammer forging process for an AZ31 alloy aircraft hub designed by one the authors of this paper was performed using a drop forging hammer with a striking energy of $63 \mathrm{~kJ}$ and the dropping part weight equal to $2100 \mathrm{~kg}$. The forming process was run according to the following design:

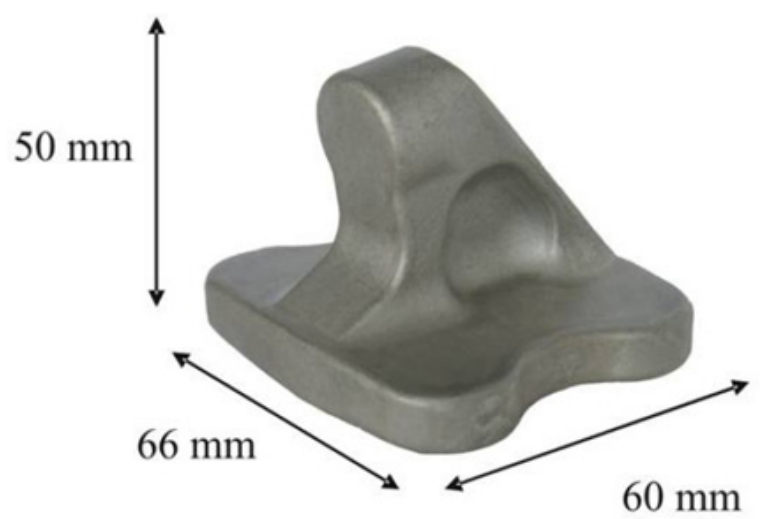

Fig. 14. Aircraft door lock set made of magnesium alloy [16]

- cutting the AZ31 alloy bar to the dimensions Ø $100 \times 93 \mathrm{~mm}$,

- workpiece heating to a temperature of $410{ }^{\circ} \mathrm{C}$, - upsetting (1 stroke) (Fig. 17a) and prelimi- 
a)

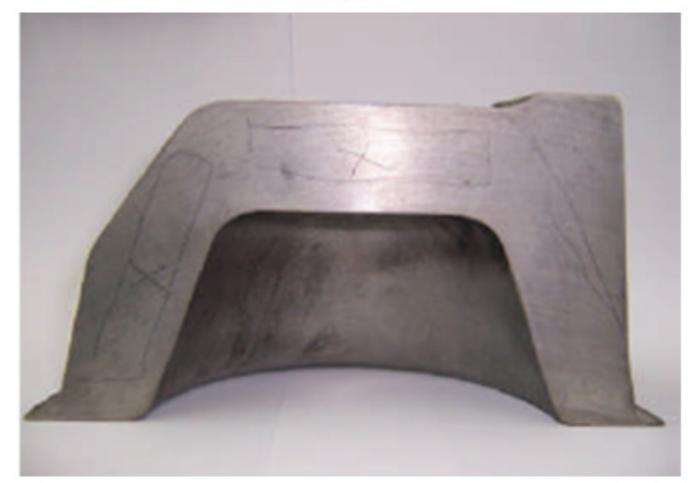

b)

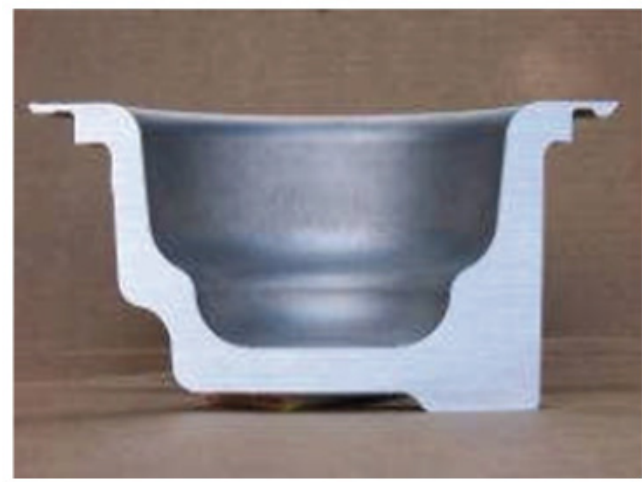

Fig. 15. Cross-sectional view of the shape of a WE43 alloy compressor casing after:

a) first forging operation - measured load $5500 \mathrm{kN}$, b) second forging operation - measured load $10500 \mathrm{kN}$ [17]

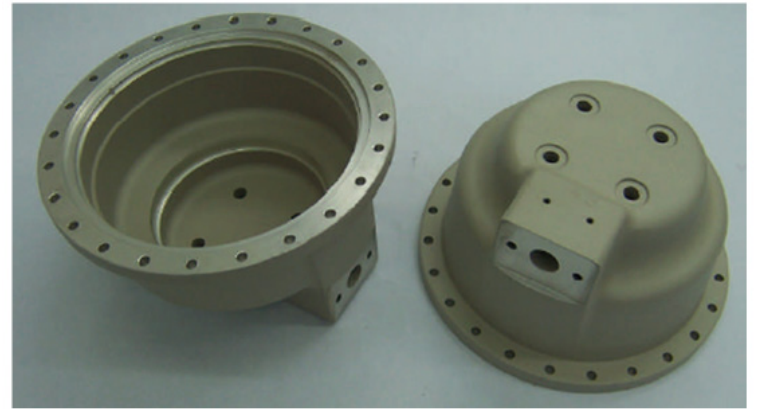

Fig. 16. WE43 alloy casing of an air-conditioning system compressor [17]

nary forging operation with underforging (3 strokes) (Fig. 17b),

- defect removal,

- workpiece heating to a temperature of $410{ }^{\circ} \mathrm{C}$,

- die forging (3 strokes) (Fig. 17c),

- flash trimming (Fig. 17d).

The die impression were lubricated with a mixture of tallow and graphite.

\section{Hammer forging process for an AZ31 aircraft lever}

The authors propose another technology of a hammer forging process for AZ31 alloy on the example of the forming process for an aircraft lever. The AZ31 lever is shown in Figure 18.

The barstock with a diameter of $40 \mathrm{~mm}$ and a length of $210 \mathrm{~mm}$ was heated to a temperature of $410^{\circ} \mathrm{C}$. Next it was subjected to bending using a hammer with a striking energy of 2100 $\mathrm{kg}$. After that, the workpiece was put in a die impression, rotated by $90^{\circ}$ and forged with a 3 $\mathrm{mm}$ underforging using the same hammer. The air-cooled forgings were subjected to flash trim- a)

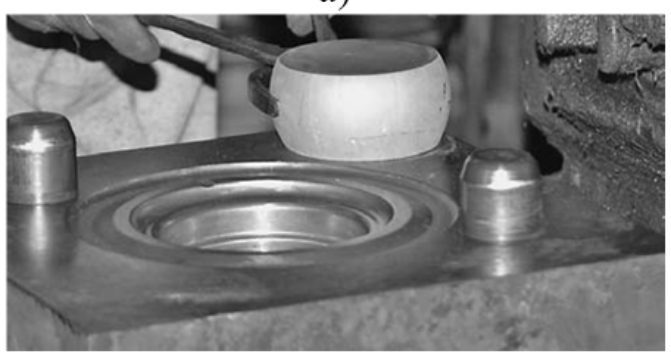

b)

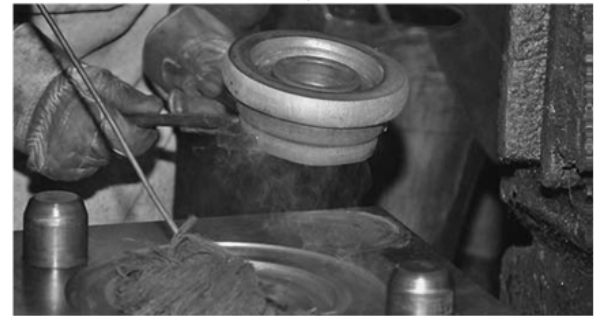

c)

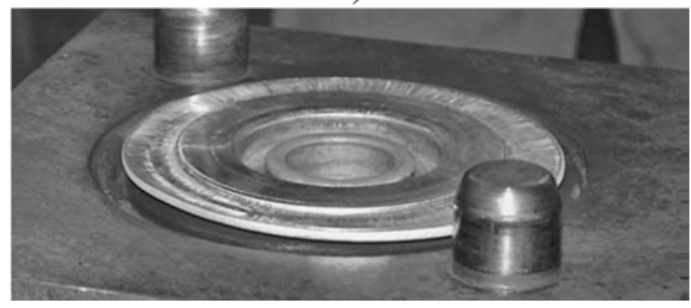

d)

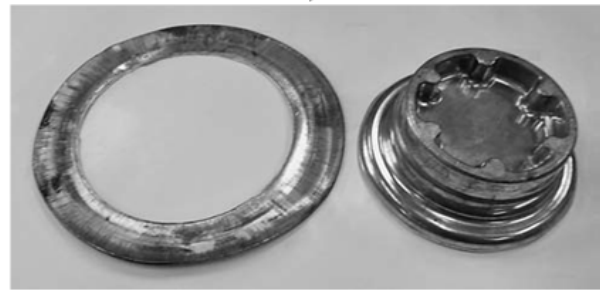

Fig. 17. Stages of the hammer forging process for an AZ31 alloy hub: a) upsetting, b) preliminary forging operation with underforging, c) die forging, d) flash trimming 


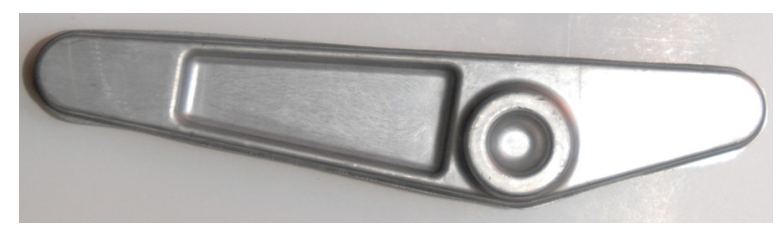

Fig. 18. Aircraft lever made of AZ31 alloy

a)

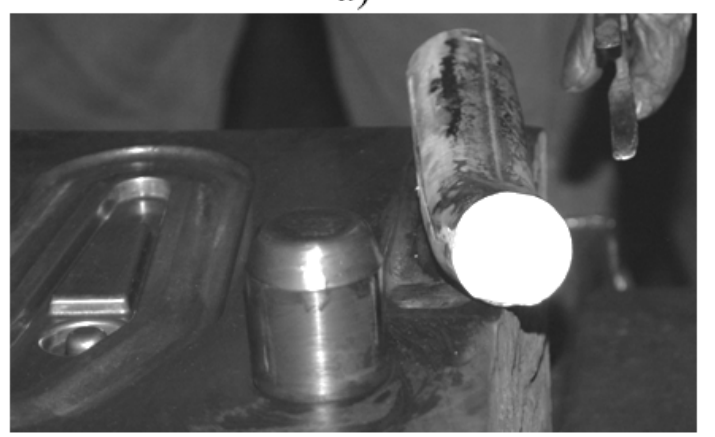

b)

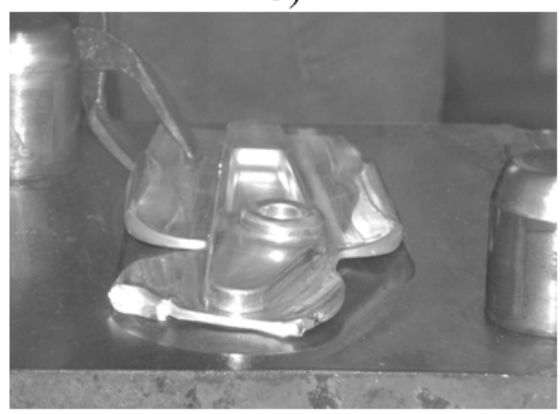

c)

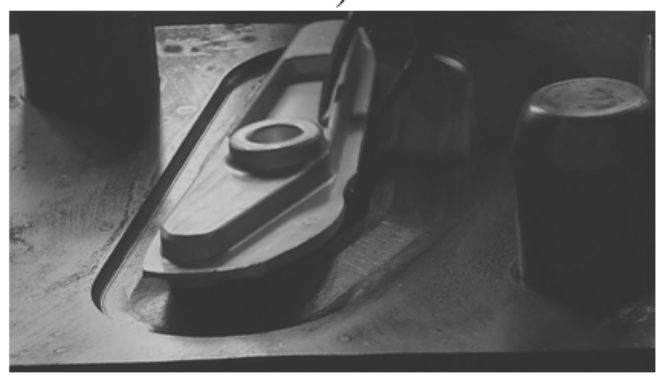

d)

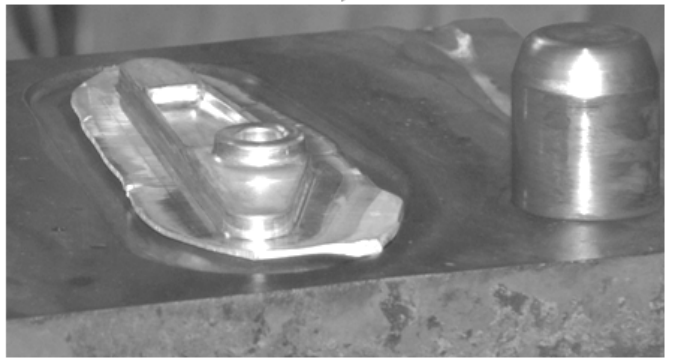

Fig. 19. Stages in the hammer forging for an AZ31 alloy lever: a) bending, b) preliminary forging operation with under forging, c) die forging, d) flash trimming ming. Next they were heated to a temperature of $410{ }^{\circ} \mathrm{C}$ and subjected to die forging. The formed forgings were subjected to flash trimming [13]. The stages of lever formation by hammer forging are shown in Figure 19.

\section{Forging process for an aircraft or automotive bracket}

Subsequently the authors propose a new forming technique for magnesium alloy flat parts with ribs (Fig. 21 and Fig. 23). The tests of producing brackets with one rib and two ribs by the new technique were performed using a three-slide forging press in compliance with the process design illustrated in Figures 20 and 22. The semi-open die forging process consisted in the upsetting of a plate heated to a temperature of $410^{\circ} \mathrm{C}$ by two side tools that had a temperature of $250{ }^{\circ} \mathrm{C}$ [10]. The tools moved horizontally with a constant speed $v=6$ $\mathrm{mm} / \mathrm{s}$, thereby forming a rib in the central part of the plate [11]. The forgings with two ribs were formed with an upper punch (Fig. 22).

\section{SUMMARY}

Magnesium alloys have a great potential as a very lightweight material that can be used to produce a number of parts for the aircraft and automotive industries. The rapid development of metal alloys and the growing interest in their forming result from the particular properties of this material, predominantly low density and high strength properties. The application of magnesium enables significant reduction of weight of means of transport, and hence considerable reduction of fuel consumption. In recent years once can observe a trend to replace parts made of casts with magnesium alloy forgings, as the latter ensure higher mechanical and functional properties. Research is conducted on new, innovative techniques for forging magnesium alloys using various forging tools (hydraulic presses, screw presses, hammer presses). This paper presented the most important forging processes for magnesium alloy parts for aircraft and automotive applications developed in recent years. The application of magnesium alloys on a global market increases by $15-20 \%$ every year. Therefore, one can predict that the use of magnesium alloy forgings will systematically increase in the immediate future. 
a)

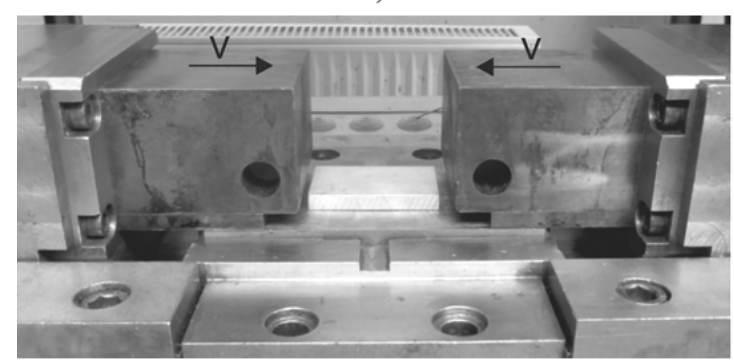

b)

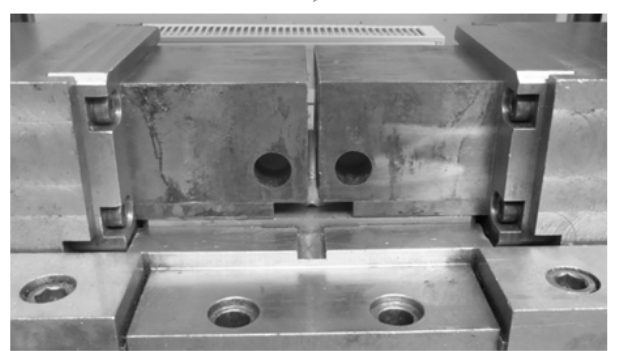

Fig. 20. Schematic design of a semi-open die forging process for AZ31 alloy brackets with one rib using a three-slide forging press

a)

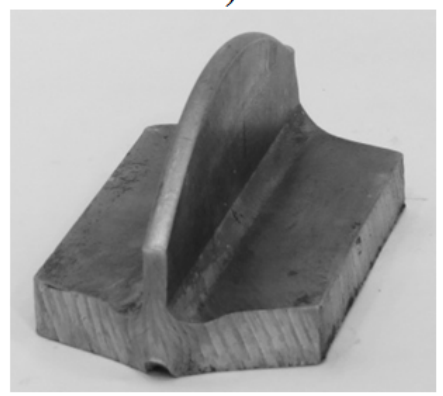

b)

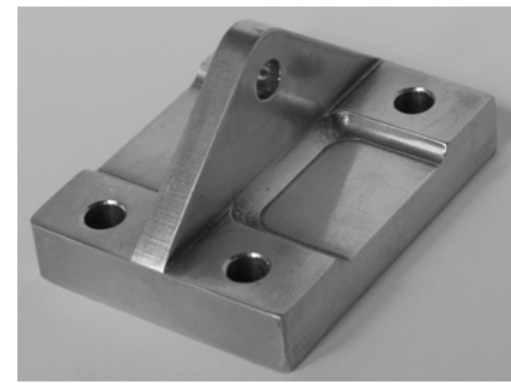

Fig. 21. Flat forging with one rib from AZ31 alloy (a) obtained in the experimental tests and finished brackets made from them (b)

a)

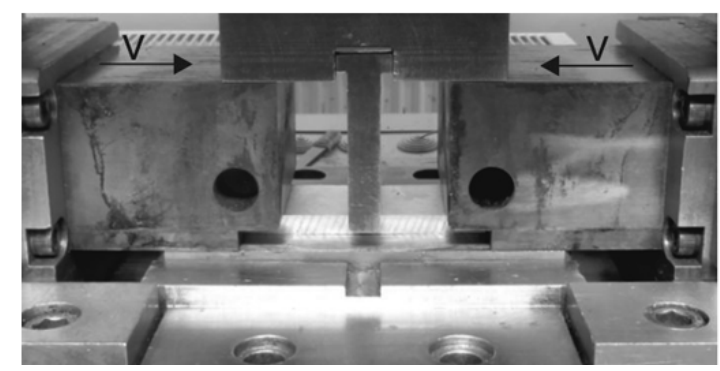

b)

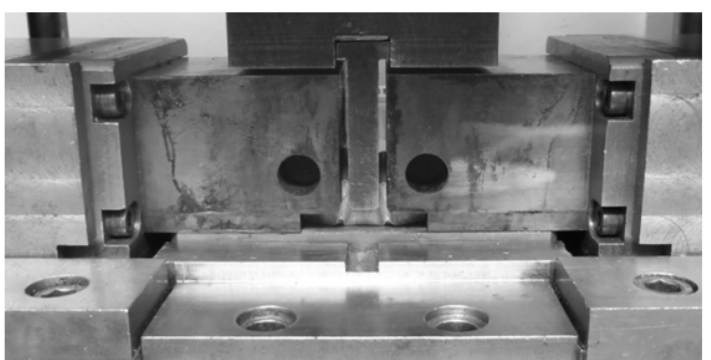

Fig. 22. Schematic design of a semi-open die forging process for AZ31 alloy brackets with two ribs using a three-slide forging press

a)

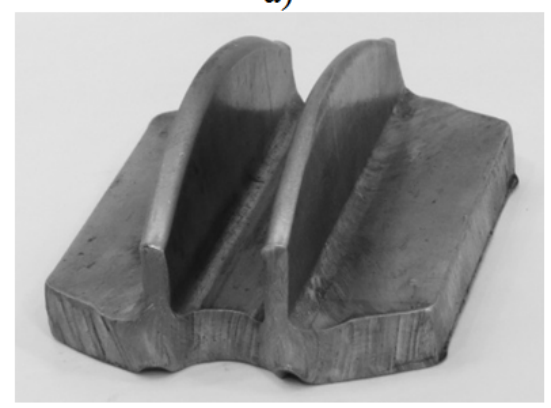

b)

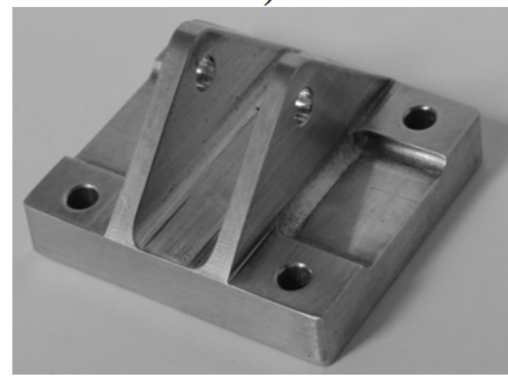

Fig. 23. Flat forging with one rib from AZ31 alloy (a) obtained in the experimental tests and finished brackets made from them (b)

\section{Acknowledgements}

Financial support of Structural Funds in the Operational Programme - Innovative Economy (IE OP) financed from the European Regional Devel- opment Fund - Project "Modern material technologies in aerospace industry", No. POIG.01.01.0200-015/08-00 is gratefully acknowledged. 


\section{REFERENCES}

1. Avedesian M., Baker H., ASM Speciality handbook. Magnesium and magnesium alloys, The Materials Information Society, USA 1999.

2. ASM Designation: B91-97, Standard specification for magnesium-alloy forgings.

3. AMTS Technology Center, http://www.palbam-defense.com/amts.html [access April 2015].

4. Bajor T., Muskalski Z., Investigations of influence of time interoperative of heat-treatment on course of drawing process and mechanical properties of wires from magnesium alloy AZ31, Ores and Non-ferrous Metals 11 (54), 2009, 697-700.

5. Balewander T., Bieniasz Ł., Śliwa R. E., Backward extrusion of AZ31 magnesium alloy sections, Hutnik - Wiadomości Hutnicze 8, 2012, 526-534.

6. Blawert C., Hort N., Kainer K.U., Automotive applications of $\mathrm{Mg}$ and its alloys, Transactions of the Indian Institute of Metals, 4 (57), 2004, 397-408.

7. Bulzak T., Tomczak J., Pater Z., Theoretical and experimental research on forge rolling process of preforms from magnesium alloy AZ31, Archives of Metallurgy and Materials 60, 2015, 439-445.

8. Davis J., Destefani J., Zorc T., ASM Metals handbook. Forming and forging, ASM International, USA 1998.

9. Dobrzański L.A., Stopy metali lekkich, http:// 157.158.19.181/platforma-/file.php/1/prezentacje-/ Stopy_metali_lekkich.pdf, Gliwice 2007 [Access April 2015].

10. Dziubińska A., Gontarz A., A new method for producing magnesium alloy twin-rib aircraft brackets, Aircraft Engineering and aerospace technology 2 (87), 2015, 180-188.

11. Dziubińska A., Gontarz A., Limiting phenomena in a new forming process for two-rib plates Metalurgija 3 (54), 2015, 555-558.

12. Friedrich H., Mordike B., Magnesium technology, Springer, Stuttgart 2006.

13. Gontarz A., Pater Z., Drozdowski K., Hammer forging process of lever drop forming from AZ31 magnesium alloy, Metalurgija 3 (52), 2013, 359-362.

14. Gontarz A., Pater Z., Dziubińska A., Winiarski G., Drozdowski K., Theoretical and Experimental Studies in Die Forging of Magnesium Alloys, Mechanik 8, 2013, 646-657.

15. Gwynne B., Lyon B., Magnesium alloys in aerospace applications, Past Concerns, Current Solutions Magnesium, Triennial International Aircraft Fire \& Cabin Safety Research Conference, 2007, http://www.fire. tc.faa.gov/2007conference/files-/Materials_Fire_ Safety/WedAM/Gwynne-Magnesium/GwynneMagnesiumPres.pdf [access May 2015].

16. Henn Y., Fein A., Project MagForming - Development of new magnesium forming technologies for the aeronautics industry, Publishable Final Activity Report, 2010, 1-58.

17. Hombergsmeier E., Fein A., MagForming - Development of new magnesium forming technologies for the aeronautic industry, Sixth European Aeronautics Days - Aerodays, Madrid 2011

18. http://criticalrawmaterials.org/critical-raw-materials/magnesium/ [access May 2015].

19. http://www.otto-fuchs.com/fileadmin/user_upload/ images/pdf/Fuchs_WI_Mg_GB_Scr.pdf [access May 2015].

20. http://www.kumz.ru/eng/win/download/176/ [access May 2015 ].

21. Iwanaga K., Tashiro H., Okamoto H., Shimizu K., Improvement of formability from room temperature to warm temperature in AZ31 magnesium alloy, Journal of Materials Processing Technology, 155156, 2004, 1313-1316.

22. Kainer K., Magnesium - Alloys and Technologies, Wiley-VCH Verlag GmbH \& Co. KGaA, Weinheim 2003.

23. Kevorkijan V., Smolar T., Dragojevic V., Lenarćić D., AZ80 and ZC71/SiC/12P closed die forgings for automotive applications - technical and economic assessment of possible mass production, Metalurgija Journal of Metallurgy, 9, 2003, 23-36.

24. Kibler H., Effiziente Serienproduktion von Magnesium-Bauteilen, Weisensee Warmpressteile errichtet innovative Schmiedelinie, Wissensportal baumaschine.de 3, 2013, 1-3.

25. Kuc D., Hadasik E., Gontarz A., Forging technology of magnesium alloys, Hutnik - Wiadomości Hutnicze, 8, 2012, 610-613.

26. Kulekci M.K., Magnesium and its alloys applications in automotive industry, The International Journal of Advanced Manufacturing Technology, 39, 2008, 851-865.

27. Oczoś K., Kawalec A., Kształtowanie metali lekkich, PWN, Warszawa 2012.

28. Płonka B., Lech-Grega M., Remsak K., Korczak P., Kłyszewski A., Kucie matrycowe wysokowytrzymałych stopów Mg - Struktura i właściwości mechaniczne $\mathrm{w}$ różnych stanach obróbki cieplnej, Archives of Metallurgy and Materials 1(58), 2013, 127-132.

29. Pekguleryuz M., Kainer K, Kaya A., Fundamentals of magnesium alloy metallurgy, Woodhead Publishing, Nowe Delhi 2013.

30. Samołyk G., A numerical analysis of AZ31 alloy warm forming by the rotary forging, Hutnik Wiadomości Hutnicze 8, 2009, 653-656.

31. Siemionek E., Dziubinski M., Testing energy consumption in the trolleybus and the bus on the chosen public transport line in Lublin, Advances in Science and Technology Research Journal 26(9), 2015, 152-153.

32. Skubisz P., Sińczak J., Bednarek S., Forgeability of $\mathrm{Mg}-\mathrm{Al}-\mathrm{Zn}$ magnesium alloys in hot and warm closed die forging, Journal of Materials Processing Technology 177, 2006, 210-213.

33. Wang Q., Zhang Z., Zhang X., Yu J., Precision forging technologies for magnesium alloy bracket and wheel, Transactions of Nonferrous Metals Society of China 18, 2008, 205-208. 